Portland State University

PDXScholar

7-23-2020

\title{
Understanding Fare Evasion Defendant Compliance: an Assessment of Criminal Records
}

Nataly Nunez Vasquez

Portland State University

Follow this and additional works at: https://pdxscholar.library.pdx.edu/open_access_etds

Part of the Criminology Commons, and the Public Policy Commons Let us know how access to this document benefits you.

\section{Recommended Citation}

Nunez Vasquez, Nataly, "Understanding Fare Evasion Defendant Compliance: an Assessment of Criminal Records" (2020). Dissertations and Theses. Paper 5554.

https://doi.org/10.15760/etd.7428

This Thesis is brought to you for free and open access. It has been accepted for inclusion in Dissertations and Theses by an authorized administrator of PDXScholar. Please contact us if we can make this document more accessible: pdxscholar@pdx.edu. 
Understanding Fare Evasion Defendant Compliance:

An Assessment of Criminal Records

by

Nataly Nunez Vasquez

A thesis submitted in partial fulfillment

of the requirements for the degree of

\author{
Master of Science \\ in \\ Criminology and Criminal Justice
}

Thesis Committee:

Brian C. Renauer, Chair

Kelsey Henderson

Danielle McGurrin

Portland State University

2020 
(C) 2020 Nataly Nunez Vasquez 


\begin{abstract}
The present study sought to examine the factors that most distinguish fare evaders who do not pay their fines and fail to appear in court from fare evaders who pay their fines and appear in court. The relationship between prior criminal history and fare evasion offenders who do not pay their fines and fail to appear in court is also explored. A sample of 24,646 defendants who received a citation for fare evasion while riding the Tri-Met transit system in Portland, Oregon were divided into two groups of fare evaders who pay and appear in court and fare evaders who do not pay and fail to appear in court. An analysis of variance (ANOVA) was conducted to find the average differences between the groups. To examine the relationship between criminal history and fare evasion defendants who do not pay and fail to appear in court, the criminal histories of a subsample of 400 defendants from both fare evader groups were analyzed. ANOVAs were conducted on the 400 defendants to evaluate the differences in criminal histories between the pay and no pay groups. Also, a logistic regression was conducted to investigate the factors most associated with non-payment and failure to appear. Furthermore, a qualitative analysis on defendants who did not pay and failed to appear was conducted using a criminal records search. Results show that there is a significant difference between the no pay and pay groups across all variables, but prior criminal history, homelessness, and repeat fare evasion are the most distinguishable factors. The findings suggest that fare evasion fines are ineffective among fare evaders who have criminal histories, are homeless, and are repeat evaders. Further research on this population is needed to improve fare evasion policy.
\end{abstract}




\section{Dedication}

To my parents Guille and Miguel. You taught me the values and practices it took to become the person I am today. You set the standards high, and for that I am grateful. Thank you for the unconditional love, support, and motivation. Mom, you taught me the importance of self-worth and how to be strong. Dad, you always push me to do better and work harder. This is for both of you, because of both of you, I love you.

To my younger siblings Allison and Matthew. Allison, you're turning into an extremely intelligent and kind young lady. Your constant admiration, love, and support makes me happy and always pushes me to work harder. Matthew, your character is like none other and your energy always makes me laugh. Watching you learn everyday makes me eager to see what you will become. This is for both of you, I love you.

Para mis abuelitos Dolores y Florencio Núñez. Gracias por enseñarme el valor de la familia y cómo apreciar las cosas pequeñas en la vida. Abuelita, siempre apreciaré los días que me cuidaba y me demostraba amor cuando mas la necesitaba. Abuelito, usted me ha enseñado que la vida es corta y debemos disfrutar y hacerla bien. Los quiero mucho.

To my grandparents Cruz and Antonio Guerrero. I will always cherish the days I spent at your house enjoying each other's company. Grandma, thank you for the constant wellness checks and lunch dates. Grandpa, I miss you and I hope you are proud watching from above. I love you both. 


\section{Acknowledgements}

A special thank you to my advisor, Dr. Brian Renauer for all your time, patience, and effort. The completion of this project was possible because of your guidance and support.

Thank you to my committee members, Dr. Kelsey Henderson and Dr. Danielle McGurrin, for your advice and insight which made this project stronger.

To my tío Jorge, thank you for always being there to offer support and guide me in the right direction.

To my tío Alejandro, thank you for always offering support, endless laughs, and love.

To Ruby, thank you for sticking by me through everything all these years.

To Aileen, thank you for always being understanding and encouraging.

To Kortney, thank you for your friendship and support in every aspect during this graduate school experience.

To Jennifer, thank you for your kindness and constant support during this challenge.

To Lorena, thank you for your companionship and support. 


\section{Table of Contents}

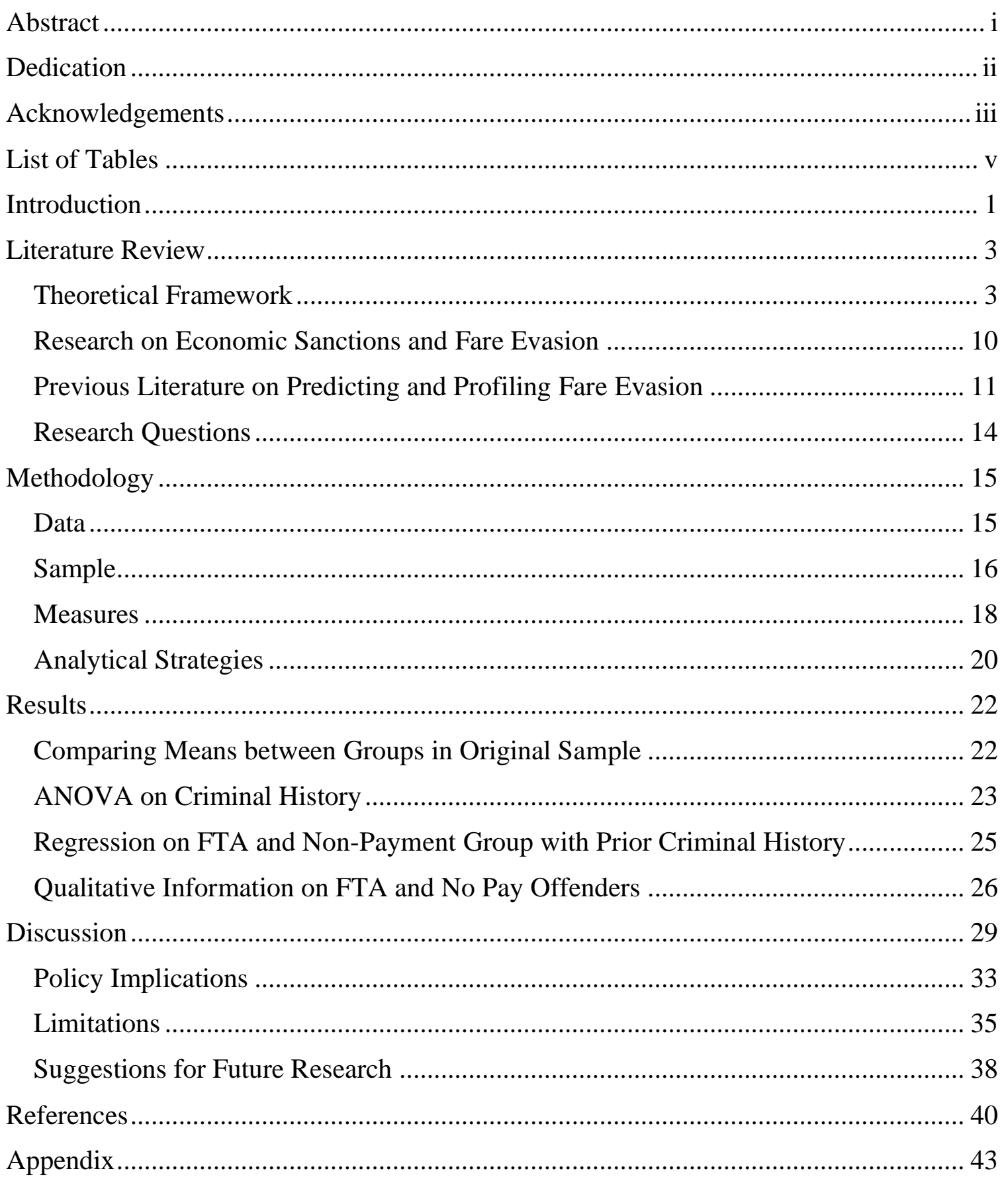




\section{List of Tables}

Table 1. ANOVA Results by No Pay and Pay Groups............................................... 23

Table 2. ANOVA Results for Criminal History by No Pay and Pay Groups .................. 25

Table 3. Logistic Regression on Prior Criminal Offenses and No Pay ............................ 26 


\section{Introduction}

The tri-county area of Multnomah, Washington, and Clackamas in Oregon has a light rail transit system referred to as the "MAX". The Tri-Met MAX system is called an "open" system in that there are no turnstiles or ticket collectors to ensure riders have paid the appropriate fare before entering a platform or getting on a train. In 1982, Gerald Fox conducted a preliminary study on the Tri-Met MAX system in which he analyzed the costs and benefits of the new self-service fare collection program (SSFC). The SSFC allowed riders to purchase their own fares through machines and did not require driver checking of fare during boarding. The SSFC was first used in Europe and became the conventional method known as the "honor" system. The North American transit systems began to adopt the self-service collection program for the advantages such as the speediness of daily operation, effective operation, improved schedules, and convenience for passengers (Fox, 1982). Though the possibility for fare evasion increased with SSFC, revenue could be made from fines or citations given to fare evaders by fare inspectors (Fox, 1982). New concerns for fare evasion evoked the emphasis for a need of a viable fare enforcement program from researchers like Fox. In response, Boyd, Martini, Rickard, and Russell (1989) reviewed a fare evasion and non-compliance "simple" model in an attempt to calculate the appropriate need of patrolling fare inspectors which was based on fare evader behavior, their perceptions on the possibility of getting caught without proof of payment, the actual possibility of getting caught, and the cost of evasion inspection. Tri-Met, which oversees public transportation in the tri-county area, primarily uses fare enforcement officers (non-sworn security officers) to conduct sweeps of riders on trains and while exiting trains. If riders are caught by officers with no fare or 
inappropriate fare, they can be given a warning, a ticket, or an exclusion (e.g. for repeat offenders). Local police also participate in some fare evasion incidents, usually at the behest of fare evasion officers and can also issue tickets, but they are most often involved in exclusion orders. The cost of a fare evasion fine at the time of this study was 175 dollars (Renauer, 2017). One major purpose for Tri-Met's use of fare evasion patrolling officers is for random inspections or patrol in an attempt to deter riders from taking advantage of the open and "honor" MAX system. Riders receiving a fare evasion ticket must appear in court to pay their fine or mail in their fine payment. A recent study conducted by Renauer (2017) analyzed Tri-Met fare evasion data and results showed that only $30 \%$ of fare evaders show up to court and pay $100 \%$ of their fine. These results call into question the effectiveness of using deterrence and fine-based models to ensure riders "honor" open system transit lines such as the MAX. Failing to appear in court for fare evasion and not paying fines yields great personal consequences including arrest warrants, applied maximum fine amounts, and the possibility of debt collection. Why are these personal costs not impacting the majority of fare evaders? The current study seeks to examine why some fare evaders are showing up to court and paying their tickets while others fail to appear in court (FTA) and have made no payments. The current study explores whether different demographic factors differentiate these two groups of fare evaders. Particular attention in this study is given to fare evaders' recent criminal histories and how the general criminal history of evaders along with other factors may have an influence on court appearances and payment decisions. 


\section{Literature Review}

Recent literature has focused on how to reduce fare evasion more effectively. In order for deterrence-based policies to be more effective, we must first understand the theory and factors that underlie these policies to improve their implementation and effectiveness. However, there is little scholarship in Criminology and Criminal Justice journals focused specifically on the topic of fare evasion defendants who fail to appear in court and do not pay their fines. The behavior this study is trying to explain is not fare evasion itself, but the act of appearing in court and paying fare evasion fines or not. Criminology and Criminal Justice theory can help explain why fare evasion defendants and repeat offenders do not appear in court or pay their fines. Understanding the characteristics of fare evasion defendants and why they fail to appear and fail to pay their fines will inform fare evasion enforcement policy making.

\section{Theoretical Framework}

Deterrence. Renauer's 2017 study found that $52 \%$ of fare evasion defendants using the MAX do not to pay fines and fail to appear in court. Relevant defendant factors must be examined to explain why deterrence, enforcement policies, and the accompanying costs to fare evaders do not appear to be working. In order to prevent future criminal action, deterrent-based policies use the threat of government sanctions to increase compliance. Intended to serve as a deterrent, Tri-Met fare evasion citations are enforced by the Multnomah County Circuit Court which imposes sanctions on fare evaders. General deterrence theory suggests that future crime could be prevented through threats of certain, severe, and speedy punishment (Nagin, 2013). 
Deterrence theory argues that individuals will refrain from committing crime if the punishment is certain (Nagin, 2013). When fare evasion defendants fail to appear in court and pay their fines, there is strong certainty of defendants being identified because court and payment records are regularly updated to incorporate the outcomes of scheduled court dates and payment collections. Fare evasion defendants could certainly have a warrant for their arrest or have unpaid fines turned over to collection agencies, further impacting their criminal record or credit history. However, certainty of punishment is also low because if defendants fail to appear and do not pay, local authorities are not actively searching for such defendants given the low severity of fare evasion cases. In other words, even when offenders do not pay, there may not be any repercussion for nonpayment (Ruback \& Bergstorm, 2006). Only in the case that the defendant is at the hand of the courts and police for a subsequent crime can the defendant be punished for previously not paying and failing to appear. There is some research that suggests that certainty of punishment is likely the strongest of deterrent factors (Decker, Wright, \& Logie, 1993).

The severity of punishment is also a component of deterrence where individuals will refrain from committing crime if the cost is considered to be severe (Nagin, 2013). Tri-Met currently has one of the highest penalties for fare evasion compared to other transit systems across the nation with the fine for fare evasion being 35 times higher than the cost of fare to begin with (Renauer, 2017). For deterrence to be effective, the punishment, in this case a fine, has to be painful and costly enough that a defendant would reconsider failing to appear in court or not paying their fines because the personal costs outweigh the benefits. Again, failing to appear in court and not paying could also be 
severe considering possibilities of an arrest warrant, perhaps resulting in a short trip to jail, and potential referral of fines to a collection agency which can impact credit rating. However, Decker, Wright, and Logie's 1993 study of active burglars concluded that increasing severity of punishment (i.e., time in prison) for burglary and robbery, "would likely have little effect on active street criminals largely because such an initiative does not alleviate the need for money, nor does it objectively reduce opportunities for crime" (p. 262). If those who do not show up to court and do not pay fare evasion fines are persons of significantly smaller financial means, it is unlikely increased monetary punishment is going to propel them to behave differently. For some it would be virtually impossible to pay such fines without gainful employment.

The speed or celerity of punishment also factors into deterrence. If punishment is swift and prompt, it is possible that the deterrent effect will be stronger. After being issued a fare evasion citation, defendants are issued a court date which is usually about a month after the citation is issued according to Multnomah County Circuit Court data. Differences in the timelines of expected court appearances could also influence a defendant's ability or willingness to appear in court. It appears the speed at which fare evaders are actually punished is slow given the time delays to court dates and the unlikelihood that the court will aggressively seek to track down defendants who miss court and do not pay fines.

In contrast to general deterrence, specific deterrence addresses the failed preventive effect of general deterrence by threat of punishment. Specific deterrence refers to the deterrent effect after reoffending and actually experiencing certain, severe, and swift punishment (Nagin, 2013). In theory, defendants who have been caught and cited 
for fare evasion would be specifically deterred after experiencing the punishment of being fined and being ordered to appear in court. Nagin's 2013 review of deterrence has shown that there is little empirical evidence that specific deterrence has an effect. Instead, specific deterrence has shown an unaffected or increased reoffending effect. Repeat fare evaders have shown that specific deterrence has little or no effect on preventing future crimes as those who chose to offend and reoffend likely disregard punishment or repercussions.

Social Bond and Stake in Conformity. Hirschi's 1969 social bond theory suggests that when social bonds are weak or broken, it increases the likelihood of crime and delinquency occurrences. An individual's relationships to conventional society are otherwise known as social bonds. Hirschi (1969) identified four types of social bonds: attachment, commitment, involvement, and belief. Attachment is the emotional relationship between individuals. Commitment is the investment in educational or occupational success. Involvement is an individual's participation in conventional activities. Belief is the embrace of the moral validity of society and conventional norms. The stronger an individual's social bonds, the more likely they are to refrain from crime and follow conventional norms. This theory builds from Durkheim's idea that conformity is established by society (Hirschi, 1969). Stake in conformity, at the most basic level, suggests that an individual has more to lose by engaging in deviant behavior when they are more invested in conventional society (Toby, 1957). These stakes will essentially influence decision making when there are potential consequences to consider (Briar \& Piliavin, 1965). According to Nagin \& Paternoster (1994), having personal capital is a form of having social bonds and they are associated with the deterrent effect. Similar to 
the rational thinking logic, defendants who are deterred view the risks of failing to appear in court too costly because they are incentivized by their investment into conventional society. Investment into society might be in the form of employment or family. With fare evasion, defendants who do not pay and fail to appear might have less stake in conformity or personal social capital. Having no stake in conformity might also be a factor in repeat offending even after being cited once before. Fare evaders who are houseless, have long criminal records, are unemployed, and are suffering from mental health and addiction crises would have very low stakes in conforming, causing them to not consider or care about the consequences of court attendance and payment of fines.

Cumulative Disadvantage. There are many factors that may make defendants not pay their fines and fail to appear in court. As previously mentioned, some defendants may be struggling with hardships such as homelessness or substance abuse. Defendants who pertain to some of these disadvantaged societal groups may have not been able to appear or pay because of the hardships previously accumulated. Criminal records represent a societal disadvantage that can have "cumulative" impacts on one's life as it is predictive of other disadvantages like unemployment and housing difficulties. Similarly, personal issues with substance abuse can have cascading cumulative disadvantages related to mental health development because of addiction, unemployment, and houselessness. These disadvantages compound over time making it more difficult for someone to be pulled back to normalcy. Hence, fare evasion defendants who have criminal records, are homeless, or have problems with substance abuse, are likely to not pay and fail to appear in court due to the related cumulative disadvantages. It is important to recognize that obeying laws, rules, and regulations can become difficult when 
individuals are restricted by hardships such as lack of employment or housing and even mental health and substance abuse (Petersilia, 2003). Ruback, Knoth, Gladfelter, and Lantz (2018) conducted a study to examine whether changes in economic sanctions would increase likelihood of payment and reduce repeat offending. Ruback et al. (2018) found that individuals who paid some to all of their fines were likely to have higher incomes. Payment of fines may be associated with defendants who hold an occupation and have financial means and therefore are likely to not have a criminal record or not report a homeless shelter address. The effects of policy changes on the poor are a more recent concern when deciding to set higher fine amounts (Cares \& Hayes, 2018). Past literature has found that imposing high economic sanctions could have negative or adverse effects because individuals will turn to deviant behavior in order to have the means to pay or because they add to existing financial hardships (Ruback et al., 2018). Researchers recognize that financial hardships possibly determine whether an individual will pay their fare evasion fine and appear in court or not (Ruback et al., 2006).

Rational Choice. Rational thinking is also a principle that influences deterrence. For deterrence to be effective, potential offenders must weigh the costs and benefits of their actions and ultimately decide to refrain from committing crime for fear of punishment (Nagin \& Paternoster, 1994). Following that logic, fare evasion defendants who appear in court and pay their fines perceive the costs of failing to appear and not paying to outweigh the benefits therefore being deterred. Defendants who do not pay and fail to appear may believe that the benefit of not having to pay outweighs the risk of being sanctioned. For some defendants who do not pay and fail to appear, the risks and costs may not even be considered. If defendants are struggling with mental health, 
homelessness, or drug and alcohol abuse, then the costs may be irrelevant to them. Combined, these components and principles that influence deterrence can be examined to understand the factors that lead defendants to appear in court and pay or not.

In the rational choice perspective, crime involves motivation and the offender's choice to commit crime in any given situational opportunity (Lilly, Cullen, \& Ball, 2015).

Following the assumption that these individuals are rational and will react to environmental situations, it could be argued that offenders are committing crime to satisfy their monetary needs or status (Lilly et al., 2015; Nagin \& Paternoster, 1994). With fare evasion, offenders who have been cited may have put their monetary needs over a citation. Once a fare evader has been cited, they must rationally decide if appearing in court and paying their fines is more beneficial than not paying and not appearing in court. Rather than appearing in court and having their fines reduced, offenders who fail to appear risk higher fine ranges. A key aspect is that offenders may not know that by appearing in court, their fine can be drastically reduced from $\$ 175$ to \$95 (Renauer, 2017). Ultimately, unpaid fines could lead to heavier costs (e.g. higher interest with a collection agency or court warrants). Perceptual deterrence offers an explanation of crime arguing that offenders choose to engage in crime when the benefits outweigh the costs (Pratt, Cullen, Blevins, Daigle, \& Madensen, 2011). Perceptual deterrence also offers a solution to crime arguing that by making the costs (legal action and penalties) less appealing, offenders will refrain from committing crime because the costs will outweigh the benefits. For example, the fare evasion and non-compliance model that Boyd et al. (1989) presented is founded on fare evader behavior and perceptions which are influenced by a fare evader's rationalization of the cost and benefit 
of getting caught and penalized. However as previously mentioned, for some fare evasion defendants who are struggling with hardships such as having no occupation, being homeless, and substance abuse, rationality and cost benefit analyses are compromised. Disadvantaged defendants might perceive little to no costs for not paying fines and failing to appear in court.

\section{Research on Economic Sanctions and Fare Evasion}

Past research has examined if payment of economic sanctions is significantly related to lower rates of recidivism. A study conducted by Ruback, Knoth, Gladfelter, and Lantz (2018) tested whether changes in economic sanctions would increase payment of fines and in turn lower recidivism. By using a prior experiment, conducting a survey of 128 offenders, and collecting local arrest data, the authors found that offenders who paid their fines in full were less likely to recidivate than those who paid little to none. Results showed that offenders who were not rearrested were more likely to have made payments toward their fines or paid in full. Results also suggested that those offenders who made no payments were likely to have committed a property crime as their most serious offense. Therefore, fare evasion defendants who did not pay their fines are more likely to be defendants who also have a criminal record and are repeat offenders in the present study. Previous offenses revealed by defendant criminal records in the current study's sample might be a predictive factor for nonpayment.

A 2006 qualitative study conducted by Ruback, Hoskins, Cares, and Feldmeyer sought to understand the factors of defendant nonpayment of fines and fees. Survey responses from 122 offenders who were sentenced to pay economic sanctions showed that paying economic sanctions would contribute to financial hardships such as inability 
to provide for a family. Responses indicated that among offenders who were ordered to pay economic sanctions, most did not find the procedure to be fair. Other explanations for nonpayment were disagreement with the sanction rationale, beliefs of unfairness, and lack of comprehension. The more prominent explanation for nonpayment was that offenders did not have the financial resources to pay their fines and fees. Ultimately, the total amount of economic sanctions and payment amounts toward fees were strong indicators of ability and willingness to pay.

\section{Previous Literature on Predicting and Profiling Fare Evasion}

There has been a growing body of fare evasion literature that attempts to understand fare evasion, predict fare evader profiles, and that makes recommendations to decrease fare evasion regarding economic sanctions. Cools et al. (2018) conducted a study based in Northern Belgium that aimed to identify socio-demographic factors that predict fare evasion by administering an online survey. The online survey was taken by 636 respondents and contained questions about general public transportation, their specific transport situation, and socio-economic variables. Responses were analyzed through a logistic regression and results showed that the average fare evader is often male, 25 years old or younger, and more likely to find penalty prices to be high. Cools et al. (2018) also found that fare evaders who think the chances of being inspected are high are less likely to commit fare evasion. These results are consistent with the idea that fare evaders are likely rationalizing their decisions to fare evade by weighing the risk and probability of getting caught.

Barbino, Salis, and Useli (2015) also conducted a study which sought to identify determinants in the fare evader profile by using interview responses of 2,177 Italian 
transit passengers regarding socio-demographic factors, travel behavior, and knowledge of fare evasion. A logistic regression and correlation analysis found that fare evaders are more likely to be young males and they will more likely choose to evade fares when the average level of fare inspections are lower. Furthermore, Barbino et al. (2015) found that fare evaders are more likely to be unemployed and have lower education levels. Based on their results, the relationship between being unemployed and increased likelihood of fare evasion could be associated with social bonds and stake in conformity. Fare evaders with criminal records may have fewer social bonds and stake in conformity and therefore the decision to evade is more prevalent.

In a study conducted by Bucciol, Landini, and Piovesan (2013), 541 bus passengers on a transit system in Reggio Emilia, Italy were interviewed in an attempt to examine the demographic profile that is correlated to fare evasion and unethical behavior. Bucciol et al. (2013) analyzed factors such as employment status, income class, and selfreported attitudes on risk (the concern or non-concern of getting caught). Past fare evasion was also analyzed and the researchers found results similar to those of Barbino et al. (2015) in that young males are more likely to be fare evaders and fare evasion is more likely to occur if the individual is unemployed (30.5\%) but less likely to occur if the individual is concerned about the risk of getting caught (-16.2\%). However, Bucciol et al. (2013) found no correlation effect between fare evasion and income or education and only a $10.4 \%$ correlation effect between fare evasion and being previously fined. The factors, employment status and attitudes of risk, analyzed by Barbino et al. (2015) support the relationship between fare evaders, deterrence, rational choice, and social bonds. 
In another qualitative study, Delbosc and Currie (2016) conducted 67 focus group interviews and online discussion forums to understand the motivations and attitudes toward fare evasion. Interviews were based on aspects of planned behavior such as perceptions and attitudes about evasion, social norms, and influences of perceptions of the cost and benefit of fare evasion. From the interviews, Delbosc and Currie (2016) identified four types of fare evaders which include the accidental evader who believes evasion is wrong, the "not my fault" evader who meant to pay but had complications, the calculated risk taker evader who intentionally evades on occasion when the benefits seem to outweigh the costs, and the career evader who almost always evades and takes pride. It is important to acknowledge how clear intent to fare evade is critical when assessing types of fare evaders (Delbosc \& Currie, 2016). Particularly with the calculated risk-taker type, the authors recognized risk takers as "gamblers" who tend to evade when they perceived the probability of getting caught is lower. Risk takers also most commonly decide to take the risk when they are only riding for "a few stops". Career evaders also take the risk when they believe they will not get caught however unlike the risk takers, they never pay fares and accept the punishment of the fine (Delbosc \& Currie, 2016). Following this logic, repeat or career evaders could possibly decide to never pay fares or fines because they anticipate no cost of getting caught and all the benefits of not paying.

Previous research has addressed the effectiveness of economic sanctions but there is still a lack of research on predictors of compliance with court orders and economic sanction payment. Within fare evasion literature, there are many studies that try to understand the fare evader profile; however, many do not provide qualitative and empirical information on convicted fare evaders with knowledge on their socio- 
demographic information (Barabino et al., 2015). The current study expands on Renauer's prior 2017 Tri-Met Examination of Fare Evasion and Fine Practices study by including a measure of defendant criminal history to the potential factors that explain payment versus non-payment. Exploring the factors that influence a defendant's inability to pay fines and failure to appear in court is essential for improving Tri-Met and other public transportation system fare evasion policies.

\section{Research Questions}

RQ1: What demographic factors distinguish fare evaders who appear in court and pay their fines from those who fail to appear and do not pay?

RQ2: Is there a relationship between fair evasion offenders who fail to appear in court and do not pay fines and criminal history?

$H_{1}$ : Defendants who fail to appear in court and fail to pay fines are more likely to have a criminal record than defendants who appear in court and pay $100 \%$ of their fees. 


\section{Methodology}

\section{Data}

The current study uses data from the Oregon Judicial Department, specifically from the Multnomah County Circuit Court. The data set in this study contains all Tri-Met public transportation fare evasion cases in court that were resolved and closed from June of 2015 to January of 2017, an approximate two-year time period. Fare evasion citations, along with the obligation to appear in court, were issued to people who were caught riding a Tri-Met MAX or bus line without a validated ticket or proof of payment. The data set contains information on whether the defendant showed up to court, the final fine imposed, and how much of the fine was paid within at least 6 months of the disposition. There was a total of 33,298 disposed cases in this data set.

The data set requested from the Multnomah County Circuit Court was originally used for a national comparison and local analysis in Multnomah County. The previous study was an examination of fare evasion and fine practices which aimed to explore deterrence and the effect of punishment of fare evasion through court conviction and the applied requirement to pay fines (Renauer, 2017). The current study expands on the previous study by adding information on defendant criminal history to assess how it may be connected to appearing in court and payment of fines. In addition, the current study specifically focuses on contrasting and more thoroughly examining the demographic characteristics of those who show up to court and pay fines compared to those who do not. 


\section{Sample}

The data for this study focuses on two samples from the original data set. First, the present study uses a sample of 24,646 fare evasion cases with all known relative characteristics included (e.g. payments made, court appearance, repeat offenders, address, and demographics) broken into two groups of fare evaders. Group one $(n=9,089)$ includes cases where defendants appear in court and pay $100 \%$ of their fines referred to as the "pay" or "payment" group. Group two $(\mathrm{n}=15,557)$ includes cases where defendants failed to appear in court and made no payments and are referred to as the "no pay" or "non-payment" group. Excluded from the study and sample were those defendants who failed to appear in court but paid $75 \%$ or more of their fine $(n=3,679)$ and defendants who failed to appear in court and paid less than $75 \%$ of their fine. Also excluded were those defendants who appeared in court and paid some but not all of their fine $(n=121)$. There may have also been defendants who were not accounted for that automatically paid their fine and did not need to appear in court. These subgroups were excluded from the study because the aim was to examine the extreme fail to appear and no pay versus appear and pay defendant cases.

A second sample was created out of groups one and two. This smaller subsample of defendants was created to look up defendant criminal records. Through random sampling, 200 defendants were selected from both group one and group two totaling a sample of 400 defendants for the criminal history analysis.

From the random sample of 400 defendants selected from the payment and nonpayment group, a new variable was created containing information on the defendant's criminal history. Taking the defendant's full name from the original data set, each 
defendant was put into the search box in the Oregon Judicial Department's online records smart search (website). Once the party search results came up, defendants with a matching name were listed along with their date of birth, case number, file date, case type, case status, and location. Defendants from the original data set were found in the results list from the online records search and identified through their full names. The match was confirmed by the defendant's full name, date of birth, and case number of the original violation which was provided by the original data set from Multnomah county. If the date of birth was different or the middle initial was missing, those cases were not considered to be the same defendant. Only historic case types that were noted as criminal violations, misdemeanors, or felonies from the records search were coded. Case types that were excluded and not coded were civil cases, specifically small claims contracts, domestic relations filings, identity changes, and personal business cases. Traffic infractions and municipal parking cases were also not included in the new data set because they were differentiated in the Oregon Judicial Department's online records and were not recognized as criminal violations. A "Prior Offense Count" variable was added to represent the amount of criminal record cases a defendant had before the original violation, meaning that the original violation did not count towards the total. Some defendants had exceptionally long criminal careers, so a decision was made to stop counting prior criminal records after five records. The date of the most recent 5 criminal cases was also recorded. The defendant criminal history was entered into a Microsoft Excel sheet. The Excel sheet included a unique identifier associated with the defendant in the original data set, offense information (i.e. felony or misdemeanor), and number of offenses with the corresponding date. The criminal history data on the Excel sheet was 
imported into the IBM Statistical Package for Social Sciences (SPSS) software and combined with the cleaned data set.

\section{Measures}

No Payment and Failure to Appear or Paid and Appeared. The dependent variable in the current study is a dichotomous variable representing defendants who failed to appear in court and made no payments toward their fare evasion fines and those fare evasion defendants who appeared in court and paid 100\% of their fine (Pay $=0$; No Pay $=$ $1)$.

Mean Prior Criminal Offense. This independent variable measures the criminal offenses of those defendants who were issued a citation and ordered to appear in court for fare evasion. This variable measures the mean number of prior criminal offenses (out of a range from zero to five) that fare evasion defendants had prior to their current fare evasion case. The count of criminal history ranged from zero to five or more offenses. The variable was coded as 0 if the defendant had no prior offenses to the original Tri-Met fare evasion after searching the Oregon Judicial Department's online records.

Any Prior Criminal History. This variable also measures the criminal history of those defendants who were issued a citation and ordered to appear in court for fare evasion. However, this criminal history variable is dichotomized to indicate if a defendant has any criminal history prior to the Tri-Met offense regardless of the count of offenses $(1=$ Yes $)$ or if a defendant has no prior criminal history in Oregon courts $(0=$ No). 
Repeat Evasion. Defendants who have more than one fare evasion citation within the two-year time period in this data set are considered repeat offenders. The repeat offender variable is dichotomized $(0=$ No, $1=$ Yes $)$.

High Repeat Evasion. Defendants who have four or more fare evasion citation records in the original data set are considered high repeat offenders. The high repeat offender variable is dichotomized $(0=$ No, $1=$ Yes $)$.

Count of Evasion Cases. This variable measures the count or raw amount of fare evasion citations each defendant has received within the original data set. The count is used to compare and determine which measures of fare evasion factors are better predictors of non-payment and failure to appear.

Months to 1st Prior Criminal Offense. This variable measures the number of months between the most recent prior criminal offense documented and the original TriMet fare evasion citation date. The time in months from the most recent criminal offenses prior to the Tri-Met fare evasion citation was measured by finding the amount of days between the offenses and dividing by 30 .

Live in PDX (Portland). This variable measures whether or not the defendant lives in Portland, Oregon $(1=$ Yes, $0=$ No) or if the defendant lives in another city and state. The "Live in PDX" variable helps determine if defendants who reside out of town are less likely to pay perhaps because they are less likely to be concerned about the ramifications of not showing up to court and paying fines.

Repeat Address (Shelter Address). The "Repeat Address" variable is a proxy measure of fare evasion defendants who are houseless, residing in homeless shelters, or are receiving services from local crisis and rehabilitative service organizations. The 
"Shelter Address" variable is dichotomized $(0=$ No, $1=$ Yes $)$. In the original data set and study, Renauer (2017) found in a frequency distribution of addresses that some addresses had a high frequency of being reported by multiple defendants. After searching for these high frequency addresses reported by multiple defendants in Google maps, they were found to be addresses to local homeless shelters and rehabilitation centers. The "Repeat Address" variable could also serve as a measure for socioeconomic status.

Demographics. The sex, race, and age of the fare evasion defendants are also analyzed. Sex is coded dichotomously $(1=$ male, $0=$ female $)$. Race is separated into two different variables, African American and Non-White, as it was in the original data set (Renauer, 2017). The African American variable is dichotomized (1 = African American, $0=$ Not African American $)$ and the Non-White variable is also dichotomized $(1=$ NonWhite, $0=$ White). The defendant age is a continuous variable.

\section{Analytical Strategies}

In the current study, the relationship between defendants with a criminal record and defendants who did not pay and failed to appear in court or paid is analyzed. In order to understand the relationship between defendants with criminal histories and defendants who do not pay and fail to appear in court or defendants who pay and appear in court, an analysis of variance (ANOVA) was conducted for the sample of 24,646 pay and no pay defendants across all variables. The ANOVA model shows the average differences between the defendants who did not pay and failed to appear in court $(\mathrm{n}=15,557)$ and the defendants who paid and appeared in court $(n=9,089)$ across all variables at the $\mathrm{p}<.001$ level. An additional ANOVA was conducted on the subsample of 400 fare evasion defendants taken from the pay group $(n=200)$ and no pay group $(n=200)$ at the $p<.001$ 
level across the criminal history variables (i.e. any prior criminal history, mean prior criminal offenses, and months to 1 st prior criminal offense). Initial frequencies were also conducted on the subsample across all variables. To test the hypothesis and the factors most associated with non-payment and failure to appear, a binary logistic regression was conducted to examine whether defendants who do not to pay and fail to appear in court are more likely to have a criminal record than those defendants who show up in court and pay $100 \%$ of their fees. The logistic regression model shows the odds ratio or proportionate change between criminal history and defendants who do not pay their fines and fail to appear in court along with other variables relating to non-payment. All analyses were conducted using IBM SPSS statistical software. Furthermore, a deeper qualitative analysis on the no pay and failure to appear group was conducted using the criminal record research, offense types, and offense details. 


\section{Results}

\section{Comparing Means between Groups in Original Sample}

In the current study, the sample was divided into two groups by offenders who appeared in court and paid all of their fine $(n=9,089)$ and by offenders who failed to appear in court and did not make any payments toward their fine $(n=15,557)$. An analysis of variance or ANOVA was conducted for the original dataset with the 24,646 cases in order to find the differences in means between the no pay and pay group at the p<.001 level (see Table 1). In the ANOVA model, the mean differences between the groups in all variables were significant. When looking at repeat offenders, defendants that have other fare evasion cases within the data set, there was a statistically significant difference in means between the group of defendants who paid and appeared in court (10.5\%) and the group of defendants who did not pay and failed to appear (39.0\%) at the $\mathrm{p}<.001$ level $(\mathrm{F}=2,580.616$, sig=.000). There was a marginally low but statistically significant difference (sig=.000) regarding high repeat offenders (defendants with a count of four or more fare evasion offenses) between the pay group (0.5\%) and the no pay group (11.5\%) with an F statistic of 1,084.337. There was also a small yet significant difference (sig=.000) between the means of the pay group (1.13) and the no pay group (1.91) when considering the count of defendant fare evasion citations during the study timeframe $(\mathrm{F}=1,904.993)$. Surprisingly, there was a significant difference (.000) between the age of the groups with the no pay group having a mean age of 34.9 and the pay group having a mean of $31.3(\mathrm{~F}=520.137)$. The mean of sex between the groups was statistically different (.000) with the no pay group having $71.9 \%$ males and the pay group having $56.2 \%$ males. There were significant differences between the means of groups (.000) 
regarding race with African American defendants representing $22.7 \%$ of the no pay group and $7.9 \%$ of the pay group $(\mathrm{F}=932.418)$ and with Non-White defendants representing $35.4 \%$ of the no pay group and $28.6 \%$ of the pay group $(\mathrm{F}=144.69)$. In regard to the repeat addresses or shelter addresses that were listed multiple times, there was a large difference between the means of the pay group (1.7\%) and the no pay group $(29.7 \%)$ where defendants reported a homeless shelter or rehabilitation facility address $(\mathrm{F}=3410.167$, sig=.000). The comparison of means between the no pay and pay groups in the original sample provides a premise for the analyses of variances explored later in the current study.

Table 1. ANOVA Results by No Pay and Pay Groups

\begin{tabular}{|c|c|c|c|c|}
\hline Variable & Mean of Pay $(\mathrm{N}=9,089)$ & Mean of No Pay $(\mathrm{N}=16,295)$ & $\boldsymbol{F}$ & $\mathbf{p}$ \\
\hline Repeat Evasion & $10.5 \%$ & $39.0 \%$ & 2580.616 & $.000 * * *$ \\
\hline High Repeat Evasion & $0.5 \%$ & $11.5 \%$ & 1084.337 & $.000 * * *$ \\
\hline Count of Evasion Cases & 1.1 & 1.9 & 1904.993 & $.000 * * *$ \\
\hline Age (continuous) & 31.3 & 34.9 & 520.137 & $.000 * * *$ \\
\hline $18-24$ & $37.6 \%$ & $22.7 \%$ & & \\
\hline $25-34$ & $33.1 \%$ & $32.5 \%$ & & \\
\hline $35-44$ & $13.6 \%$ & $21.3 \%$ & & \\
\hline $45-54$ & $8.5 \%$ & $15.1 \%$ & & \\
\hline $55+$ & $7.2 \%$ & $8.3 \%$ & & \\
\hline Sex (Male) & $56.2 \%$ & $71.9 \%$ & 667.233 & $.000 * * *$ \\
\hline African American & $7.9 \%$ & $22.7 \%$ & 932.418 & $.000 * * *$ \\
\hline Non-White & $28.6 \%$ & $35.4 \%$ & 144.69 & $.000 * * *$ \\
\hline Repeat Address (Shelter Address) & $1.7 \%$ & $29.7 \%$ & 3410.167 & $.000 * * *$ \\
\hline
\end{tabular}

Note: $\mathrm{p}<.001 * * *$

\section{ANOVA on Criminal History}

From the original sample of 24,646 pay and no pay defendants, a random sample of 200 defendants was taken from the pay and no pay groups for a refined sample of 400 fare evasion defendants. The criminal histories for the sample of 400 defendants were accessed through a publicly open web portal provided by the Oregon Judicial Department. The primary question this study seeks to examine is whether criminal history is related to not showing up in court and not paying fare evasion fines or to 
showing up and paying. Frequency analyses were conducted on the pay and no pay groups to show the count and percentage differences between the two groups (see Appendix A). An analysis of variance (ANOVA) was used to examine the mean difference in criminal histories between the group that paid their fine and appeared in court $(\mathrm{N}=200)$ and the group that did not pay and failed to appear in court $(\mathrm{N}=200)$ across criminal history related variables at the $\mathrm{p}<.001$ level (see Table 2 ). When comparing the pay and no pay group regarding whether or not defendants have had any prior offense before the original Tri-Met citation, there was a statistically large difference in the means between the two groups. Out of the no pay and failure to appear group, $55.0 \%$ of defendants had a criminal history compared to only $16.0 \%$ of defendants that paid and showed up to court $(\mathrm{F}=79.873$, sig=.000). There was a statistically significant difference between defendants who paid and did not pay based on the average or mean of prior criminal offenses before the Tri-Met fare evasion case with the no pay group having a mean of 1.94 prior criminal offenses and the pay group having a mean of $0.30(\mathrm{~F}=98.592$, sig=.000). When accounting for the number of prior offenses, $45.5 \%$ of defendants in the no pay group had zero prior offenses while $84.5 \%$ in the pay group had zero prior offenses. There were differences between the defendants in the no pay and pay groups who had one, two, three, and four prior offenses. However, there was a larger difference between defendants in the two groups with $29.0 \%$ of defendants in the no pay group having five or more prior offenses and only $1.0 \%$ of defendants in the pay group having five or more prior offenses. There was also a significant difference between groups when accounting for the mean number of months between their most recent criminal offense and the fare evasion offense with the no pay group having a mean of 23.8 months and the 
pay group having a mean of 59.7 months $(\mathrm{F}=18.608$, sig=.000). The number of months were grouped into categories beginning with less than a month, one to three, four to six, seven to nine, ten to twelve, and thirteen and over months. There were differences for each of the month categories with notable differences at one to three months between the no pay group (24.6\%) and the pay group (6.5\%) and at thirteen and over months with the no pay group having $42.2 \%$ and the pay group having $77.4 \%$.

Table 2. ANOVA Results for Criminal History by No Pay and Pay Groups

\begin{tabular}{llllc}
\hline Variable & Mean of Pay (N=200) & Mean of No Pay (N=200) & $\boldsymbol{F}$ & $\boldsymbol{p}$ \\
\hline Any Prior Criminal History & $16.0 \%$ & $55.0 \%$ & 79.873 & $.000^{* * * *}$ \\
Mean Prior Criminal Offenses & 0.30 & 1.94 & 98.592 & $.000^{* * *}$ \\
0 Prior Offenses & $84.5 \%$ & $45.5 \%$ & & \\
1 Prior Offense & $8.0 \%$ & $13.0 \%$ & & \\
2 Prior Offenses & $4.0 \%$ & $5.5 \%$ & & \\
3 Prioir Offenses & $1.5 \%$ & $3.5 \%$ & & $.000^{* * *}$ \\
4 Prior Offenses & $1.0 \%$ & $3.5 \%$ & & \\
5+ Prior Offenses & $1.0 \%$ & $29.0 \%$ & & \\
Months to 1st Prior Criminal Offense & 59.7 & 23.8 & & \\
< 1 mo. & $6.5 \%$ & $11.9 \%$ & & \\
1-3 mo. & $6.5 \%$ & $24.6 \%$ & & \\
4-6 mo. & $9.7 \%$ & $11.0 \%$ & & \\
7-9 mo. & $0.0 \%$ & $5.5 \%$ & & \\
$10-12$ mo. & $0.0 \%$ & $4.6 \%$ & & \\
$13+$ mo. & $77.4 \%$ & $42.2 \%$ & & \\
\hline Note: $p<001 * * *$ & & &
\end{tabular}

\section{Regression on FTA and Non-Payment Group with Prior Criminal History}

Defendants in the no pay and failure to appear group were hypothesized to be more likely have a criminal record than defendants in the pay group. A binary logistic regression was conducted with "No Pay and Failure to Appear" as the dependent variable and the factors most associated with no pay and failure to appear as the independent variables to compare this group to the pay group (see Table 3). Results from the regression show that the strongest variable related to non-payment and failure to appear in court is the repeat or shelter address proxy measure with an odds ratio of 128.695 and a standard deviation of 1.031 ( $\mathrm{sig}=.000)$. When considering the effect size of repeat 
addresses, the findings indicate that defendants who do not pay their fines and fail to appear in court are almost 129 times (128.695) more likely to report living in a shelter address than defendants who pay and appear in court. The second strongest variable related to the no pay and failure to appear group is the any prior criminal history measure with an odds ratio of 5.281 and a standard error of 0.294 (sig=.000). Defendants in the no pay and fail to appear group are a little over five times (5.3) more likely to have a prior criminal history than the defendants in the pay group. Also significant at the $\mathrm{p}<.001$ level was the repeat fare evasion variable with an odds ratio of 3.843 and a standard error of 0.345 (sig=.000). Defendants in the no pay group are about four times (3.8) more likely to have had repeat fare evasion cases than the defendants in the pay group. Significant at the $p<.01$ level, the Non-White variable had an odds ratio of 2.503 and a standard error of 0.284 ( $\mathrm{sig}=.001)$. The Non-White variable suggests that defendants in the no pay group are two and a half times (2.5) more likely to not be White than the defendants in the pay group. The variables that were not significant were age (.339), sex (.335), and live in Portland (.593).

Table 3. Logistic Regression on Prior Criminal Offenses and No Pay

\begin{tabular}{lccccccc}
\hline Control & B & S.E. & Wald & $\boldsymbol{d} f$ & Sig. & O.R. & 95\% C.I. \\
\hline Any Prior Criminal History & 1.664 & 0.294 & 31.946 & 1 & $.000 * * *$ & 5.281 & {$[2.96-9.405]$} \\
Age (continuous) & 0.010 & 0.011 & 0.915 & 1 & .339 & 1.01 & {$[0.99-1.03]$} \\
Repeat Address (Shelter Address) & 4.857 & 1.031 & 22.177 & 1 & $.000 * * *$ & 128.695 & {$[17.04-971.72]$} \\
Live in PDX & 0.151 & 0.283 & 0.285 & 1 & .593 & 1.163 \\
Non-White & 0.917 & 0.284 & 10.454 & 1 & $.001 * *$ & 2.503 & {$[0.67-2.03]$} \\
Repeat Evasion & 1.346 & 0.345 & 12.184 & 1 & $.000 * * *$ & $3.843-4.36]$ & {$[1.95-7.56]$} \\
Sex (Male) & 0.278 & 0.288 & 0.929 & 1 & .335 & 1.32 & {$[0.76-2.32]$} \\
Constant & -2.273 & 0.473 & 23.101 & 1 & .000 & 0.103
\end{tabular}

\section{Qualitative Information on FTA and No Pay Offenders}

The current study aims to assess disparities in fare evasion cases by exploring criminal records of defendants who do not pay their fines and fail to appear in court. To 
get a more in-depth picture of how criminal history relates to non-payment, the criminal records of five random defendants from the no pay and failure to appear group with five or more prior offenses were examined. One defendant, identified as defendant 208 in the data set, had prior offenses that not only included multiple "Offense Violation" cases, but also multiple "Offense Misdemeanor" and "Offense Felony" cases dating from recent years to back before 2000. Some of defendant 208's cases include misdemeanors for having alcohol in the park and harassment, misdemeanors for interfering with public transport, disorderly conduct, and offensive littering, and felony cases for possession of cocaine.

Another defendant with the identifying number 349 has had numerous misdemeanor and felony cases within the last five years including class B and C felony cases for possession and distribution of methamphetamine, misdemeanors for having alcohol on public property, and misdemeanors for offensive littering. A third defendant, identified as 364 , has had misdemeanor cases for disorderly conduct and interfering with peace and parole, harassment disorderly conduct in the second degree, felony cases for burglary in the first degree, assault in the fourth degree, and criminal mischief in the second degree. Defendant 370 has had multiple misdemeanors and felony cases within one-year time frames. Defendant 370, for example, had two separate misdemeanors, both for possession of cocaine with only a three-month time period in between cases. Defendant 370 also had felony cases for possession of controlled substances and criminal trespassing.

Some defendants with multiple prior offenses however did not have felony or misdemeanor cases on their record. Instead, some defendants were convicted multiple 
times of only fare evasion. For example, defendant number 393 was convicted of fare evasion because they had no proof of payment several times between 2011 and 2016. Overall, all the defendants whose online criminal records were examined have had multiple previous offense violations for fare evasion and most had more serious offenses on their records as well. Furthermore, all the examined defendants had similar cases or even identical repeated charges like drug and social disorder related offenses. 


\section{Discussion}

The current study aimed to examine the relationship between fare evasion defendants who do not pay their fines and fail to appear in court and fare evasion defendants who do pay and appear in court in relation to their criminal histories. The study also aimed to understand the factors that better distinguish fare evaders who do not pay and fail to appear. An ANOVA comparing prior criminal history between the two groups showed a large difference between the pay and no pay group was apparent. The largest difference between the groups was the mean of prior criminal offenses where the pay group had a mean of 0.30 and the no pay group had a mean of 1.94 criminal offenses with a significance of $.000(\mathrm{~F}=98.592, \mathrm{p}<.001)$. Out of the 200 defendants in the no pay group, over half of them had one to five or more prior criminal offenses. More notable, $13.0 \%$ of no pay defendants had only one offense and $29.0 \%$ had at least five or more prior criminal offenses compared to the pay group where only $8.0 \%$ had one prior offense and only $1.0 \%$ of defendants had five or more. The timeline of prior offenses could also be telling of a defendant's general deviant behavior. Out of the 109 defendants in the no pay group with any prior offense, $11.9 \%$ of those defendants had a prior offense on their criminal record within less than a month, $24.6 \%$ of them within one to three months, $11.0 \%$ of them within four to six months, $5.5 \%$ of them within seven to nine months, $4.6 \%$ of them within ten to twelve months, and $42.2 \%$ of them within thirteen months or more. Moreover, these findings coincide with the results reported by the logistic regression which suggest that defendants in the no pay and failure to appear group are 5.3 times more likely to have a prior criminal offense than the defendants in the pay and appear group. Cools et al. (2018) mentioned that from their sample of 636 survey 
respondents, more than $25 \%$ of people in the entire sample have had at least one prior fare evasion citation and when compared to the current study, that amount is nearly doubled with $41.5 \%$ of defendants in the no pay group being repeat fare evaders with at least one prior fare evasion citation. Based on their results, Cools et al. (2018) mentioned that very few factors help in predicting the profile of a fare evader. However, the current study found support in the identification of criminal records in addition to repeat fare evasion as a predicting factor of fare evasion, non-payment, and failure to appear in court. Criminal history could be an indicator of non-payment of fines and failure to appear in court because of cumulative disadvantages, differing rational thinking, and lack of stake in conformity. Moreover, those defendants with criminal histories and those in the no pay and failure to appear group who also were repeat offenders show that specific deterrence has little to no preventive effect on future evasion. Being that some defendants with a criminal record could be financially disadvantaged or have hardships such as substance abuse (37.0\% listed a shelter address), they are reluctant to pay a fare let alone a fine in a higher monetary range. The defendants belonging to this population may perceive the benefits of not paying to outweigh the costs because they have little to nothing to lose. Furthermore, with no potential costs defendants are also likely to have little personal capital within society. Subsequently, the defendants in the no pay and FTA group are not deterred by existing transit system fare enforcement policies because their perceptions of severe and certain punishment are likely muted through the disadvantages and day-to-day obstacles they face.

The statistical differences in the means of demographic variables for the defendants in the no pay group and the pay group were all significant according to the 
ANOVAs. The significant demographic variables include living in shelters, repeat fare evasion, and race. Previous studies have found that fare evasion defendants are usually young males and though there were significant differences between the means in age and sex of the defendants in both groups as well, that might have been because of random sampling. However, race was significant in the logistic regression suggesting that defendants in the no pay group are 2.5 times more likely to be Non-White than defendants in the pay group. Some notable findings were that the defendants from the no pay group who listed a repeat address had a mean of $29.7 \%$ while the pay group defendants who listed a repeat address had a mean of $1.7 \%$. The logistic regression showed that no pay defendants who listed a repeat address were 128.7 times more likely to have any prior criminal history than the pay defendants who listed a repeat address. Results indicate that at least one third of the no pay fare evasion defendants with a criminal history have been associated with a homeless shelter or a rehabilitation center. The hardships of this population that could lead to differences in rational decisionmaking could be explained by cumulative disadvantages. Accumulating hardships that minority (Non-White) and homeless populations experience can be attributed to their social and economic statuses. Experiencing homelessness, drug and alcohol abuse, and even mental health issues may influence defendant reasoning in favor of fare evasion, non-payment of fees, and failure to appear in court. After defendant rational thinking and stake in conformity is compromised, they are less likely to be concerned by deterrencebased policies regardless of punishment severity, certainty, and celerity. This is especially true for those defendants who are repeat offenders and have criminal histories as the experience of being punished, specific deterrence, has no effect on future offending. 
When selected at random, the no pay and failure to appear group defendants had similar criminal offenses or types on their record. The defendants whose criminal backgrounds were further investigated had offenses that are more serious than fare evasion, including misdemeanors and felonies. Not only were the offenses more serious, but there were several criminal offenses that all occurred months apart over the last several years. With the accumulating convictions and court fees, it is likely that these defendants would give little importance to initially paying a fare, paying a fare evasion citation, or even appearing in court for a fare evasion violation. As generally mentioned by criminological studies, Clarke et al. (2010) also suggested that it is possible that a small number of individuals are responsible for multiple or a larger amount of the fare evasion cases. Therefore, in the current study, it is possible that the individuals responsible for a large amount of the fare evasion cases could be a few defendants in the no pay group with a criminal record in combination with other factors. The information from a deeper analysis into a few defendant criminal records is exemplary of how general and specific deterrent based polices do not function for the no pay, failure to appear, and repeat evading population. The defendants in this group might also be likely to fail to appear in court and pay their fees because of lack of stake in conformity and social bonds. Given the severity and amount of criminal records these defendants had on their criminal histories, it is likely that they are not personally invested into social and conventional norms. These particular defendants were heavily involved in more serious types of criminal activity where the risks are costlier suggesting their rational thinking leads them to disregard any repercussion or costs. Moreover, the qualitative information also shows that these no pay defendants with prior criminal histories have records for 
crimes involving illicit drug and alcohol consumption or handling. This supports the suggestion that mental health or substance abuse by defendants may add to existing cumulative disadvantages and influence rational decision making.

The analyses in their entirety show that there is a fundamental difference between fare evaders who pay and appear in court and fare evaders who do not pay and fail to appear in court. The differences in means between the pay and no pay groups and the nature of some of the no pay fare evaders' criminal records suggest that those who do not pay their fines and do not appear in court are more likely to have committed similar acts before and will continue. Factors relating to prior criminal offenses, homelessness or low socioeconomic status, repeat fare evasion, and even race are associated with defendant likelihood of failing to appear in court and not paying their fees. Therefore, the hypothesis that defendants who fail to appear in court and fail to pay fares and fees are more likely to have a criminal record than defendants who show up in court and pay their fees is accepted based on the results of this study.

\section{Policy Implications}

Though the possibility for fare evasion increased with self-service or honor system programs, revenue could be made from fines or citations given to fare evaders by fare inspectors (Fox, 1982). Also, the costs of auditing all fares outweighs the labor costs of fare inspectors (Boyd, 1989). The problem with fare inspectors however, is that it is the costliest form of fare evasion inspection or control (Fox, 1982). While increased inspection would increase revenue in fares, it would also increase cost in inspector enforcement (Boyd, 1989). The increase in revenue with increased fare citations from inspectors also assumes that individuals will pay those fines. The findings in the study 
conducted by Bucciol et al., (2013) and the results from the current study suggest that increasing fares and fines would not increase transit system revenues at least with fare evaders like the defendants in the target sample in the current study. Remember that only $30 \%$ of fare evaders over a two-year time period actually paid their fine in full after six months in the original data set (Renauer, 2017). Those people who are not paying their fines, as portrayed by the sample and results from the current study, are mostly repeat fare evaders, have criminal records, and suffer from housing or other crisis issues. In a report made to assess the deterrent effect of increasing the issuance of fare evasion fines in a transit system in Canada, Clarke, Contre, and Petrossian (2010) suggested that when deciding to commit fare evasion, an individual considers the certainty of being caught more heavily than the severity (price) of the punishment. However, if the severity of punishment is increased, then fare evasion would likely also decrease. Clarke et al. (2010) suggested refining policy around repeat offenders like the individuals in the current study's target sample. Cools et al. (2018) suggested directing enforcement around individuals in the "younger" age range with methods such as promoting information on the fare evasion processes.

The findings from the current study show that policy regarding fare enforcement and fare evasion citations should change. Tri-Met has one of the costliest fare fines in the country (Renuaer, 2017); however, results show that these high fare evasion fines are not effective for approximately $70 \%$ of fare evaders and are especially ineffective with the individuals who have had prior criminal histories, are repeat fare evaders, and who are homeless. The defendants belonging to these particular groups are likely to not pay their fines and appear in court regardless of higher fine amounts and other repercussions. Some 
reasons why fare evaders might not pay the appropriate fare could be attributed to their disadvantages such as homelessness, substance abuse issues, or financial hardships. While Tri-Met does have reduced fare programs for low income riders, some individuals may not be able to pay fares for every ride. Riding payment plans may also not be effective with this population either and could end in debt and collections. Giving this population "free" passes would be costly to Tri-Met, but also raise fairness concerns with passengers who do pay the appropriate fares or fines. Further research should be conducted to understand fare evasion and riding purposes among the chronic fare evading population. Additional research on public opinion of fare evasion, experiences on the MAX, and reduced fare programs could help Tri-Met shape policy discussions too.

\section{Limitations}

To ensure the quality and validity of the research, the current study was carefully conducted, organized, and executed, however there were some limitations. Ultimately, this particular study is specific to Oregon's Multnomah County Judicial Department, the tri-county metropolitan area, and their Tri-Met transit system. The predictive factors and relative results or indications are specific to this urban setting, but they still may be applicable to other cities, states, countries, or even other types of transit systems. Specific to the present study's setting are administrative processes, court processes, and the fine amounts imposed. The way that citations are issued by the transit system, the way cases are disposed, the way sanctions are imposed in courts, and the amount in fine ranges that are applied could produce different but similar dynamics of fare evasion, fine, and court outcomes. Furthermore, the specific demographics and socioeconomic statuses of the population who use the Tri-Met transit systems differ from other areas and regions but 
findings may be applicable. All of these factors may have influenced the results of the study and affected its generalizability; however, the findings still contribute to fare evasion scholarship.

Another limitation to the current study was the limited information on defendant criminal offenses. Although criminal records are public information which are accessible through the internet, there still may be some information missing from cases listed online. When searching for certain cases or a defendant's name, some case descriptions are minimal, or case dockets are missing. This prevents a deeper analysis of individual cases when examining defendant criminal records. Though more information on defendant cases and their criminal records would have been useful, knowing the nature of defendant cases provided enough qualitative information for the purpose of the current study. Each defendant's criminal record search provided search results with all known cases, criminal offense types (i.e. felony, misdemeanor), offense descriptions, and some details such as dates, locations, case statuses, charge statues and levels, disposition events, etc. Therefore, enough information on each case was accessible to interpret defendant criminal records.

Though the original full data set contains personal and identifying information, there was also some uncertainty about defendant to case association. Using information such as a full name, date of birth, and case numbers, a defendant could be "smart" searched in the court's online records. Results will display a list of defendants and their previous offenses matching the search information entered. However, it is common that an individual defendant will be listed multiple times in separate entries. According to Multnomah County court clerks, the reason why an individual defendant can be listed 
multiple times is because of file entry coding error or misconnection. When clerks input cases into the online court records and defendants have multiple cases, the clerks do not make the association and they enter the defendant as a new entry. This made it possible for different defendants to appear in the search results list. However, Multnomah County court clerks also stated that when searching a defendant with multiple entries, the single defendant can be associated with different entries by matching full names and dates of birth. When searching and coding defendant criminal records in the current study, each case entry was cross checked with full names and dates of birth to ensure they were the same defendant.

A major limitation to the present study is the missing factor of defendant socioeconomic and financial status. The listed address of defendants is available in the original data set; however, the addresses were not used for neighborhood analyses in the current study. A more qualitative approach that focuses on the personal and socioeconomic information of the sample or participants would be the appropriate and only adequate form of obtaining the richest information. Instead, in the current study the repeat or "shelter" address was incorporated to examine the relationship between those defendants who do not pay their fines and fail to appear in court and who also listed an address of a homeless shelter or rehabilitation center. This created a more predictive factor that supplements defendant socioeconomic status. Though the present study had limitations, the findings still are empirically valuable additions to the growing literature on fare evasion. 


\section{Suggestions for Future Research}

As previously mentioned, there are qualitative methods in which scholars could add to the current literature (Delbosc \& Currie, 2016). Having qualitative information on defendant or fare evader socioeconomic status would make for a better predictive study in which factors of nonpayment and failure to appear in court could be examined. For example, fare evasion defendants could complete surveys or participate in interviews where their responses show reasoning for nonpayment or failing to appear in court. Questions in the survey or interviews could also inquire participants about their preferences on administrative processes, court processes, or even suggestions on preventing fare evasion. Observations in a natural experiment on the interactions between fare evasion inspectors and passengers with or without proof of payment would also bring contributions to this area of research (Bucciol et al., 2013). Making sense of the qualitative responses would create a better understanding of fare evasion. For the purpose of policy improvement, future research could lead in the direction of fare evader riding purposes. Regardless of failure to appear in court and nonpayment, knowing the purpose of riding or passenger destinations could be telling of intentional fare evasion. Passengers may be willing to ride without the appropriate fare because they need to be at a destination and just cannot afford paying. Some may just be "joy riding" to pass the time or may use transportation for transitions between criminal activity. Investigating the reasons or situational factors for fare evasion might help alleviate fare evasion. These predictive studies with qualitative strategic approaches could help inform policy making and anticipate policy effectiveness. Being that the recent literature is focused on finding 
solutions to fare evasion without the heavy use of economic sanctions (Barabino et al., 2015), the direction of future research could heavily rely on these methods. 


\section{References}

Barabino, B., Salis, S., \& Useli, B. (2015). What are the determinants in making people free riders in proof-of-payment transit systems? Evidence from Italy. Transportation Research Part A: Policy and Practice, 80, 184-196.

Boyd, C., Martini, C., Rickard, J., \& Russell, A. (1989). Fare evasion and noncompliance: A simple model. Journal of Transport Economics and Policy, 189197.

Briar, S., \& Piliavin, I. (1965). Delinquency, situational inducements, and commitment to conformity. Social Problems., 13, 35.

Bucciol, A., Landini, F., \& Piovesan, M. (2013). Unethical behavior in the field: Demographic characteristics and beliefs of the cheater. Journal of Economic Behavior \& Organization, 93, 248-257.

Cares, A. C., \& Haynes, S. H. (2018). Restitution: A Different Kind of Economic Sanction? Criminology \& Public Policy, 17(4), 815-823.

Clarke, R. V., Contre, S., \& Petrossian, G. (2010). Deterrence and fare evasion: Results of a natural experiment. Security Journal, 23(1), 5-17.

Cools, M., Fabbro, Y., \& Bellemans, T. (2018). Identification of the determinants of fare evasion. Case studies on transport policy, 6(3), 348-352.

Crozier, W., \& Garrett, B. L. (2019). Driven to Failure: Analysis of Failure to Appear and Pay Driver's License Suspension Policy in North Carolina. Available at SSRN 3440832 .

Crutchfield, R. D., Fernandes, A., \& Martinez, J. (2010). Racial and ethnic disparity and criminal justice: How much is too much? The Journal of Criminal Law and 
Criminology (1973-), 100(3), 903-932.

Delbosc, A., \& Currie, G. (2016). Four types of fare evasion: A qualitative study from Melbourne, Australia. Transportation Research Part F: Traffic Psychology and Behaviour, 43, 254-264

Fox, G. D. (1982). Tri-Met's Self-Service Fare Collection Program. Transportation Research Record, 857, 32-38.

Hirschi, T. Causes of Delinquency. 1969, Berkeley.

Lilly, J. R., Cullen, F. T., \& Ball, R. A. (2015). Criminological Theory: Context and Consequences (6th ed.). Thousand Oaks, CA: Sage.

Nagin, D. S. (2013). Deterrence in the twenty-first century. Crime and justice, 42(1), 199-263.

Nagin, D. S., \& Paternoster, R. (1994). Personal capital and social control: The deterrence implications of a theory of individual differences in criminal offending. Criminology, 32(4), 581-606.

Petersilia, J. (2003). When prisoners come home: Parole and prisoner reentry. Oxford University Press.

Pratt, T. C., Cullen, F. T., Blevins, K. R., Daigle, L. E., \& Madensen, T. D. (2006). The empirical status of deterrence theory: A meta-analysis. Taking stock: The status of criminological theory, 15, 367-396.

Renauer, B.C. (2017). Examination of Fare Evasion and Fine Practices 2015-2017. Submitted to TriMet.

Ruback, R. B., \& Bergstrom, M. H. (2006). Economic sanctions in criminal justice: Purposes, effects, and implications. Criminal Justice and Behavior, 33(2), 242- 
273.

Ruback, R. B., Hoskins, S. N., Cares, A. C., \& Feldmeyer, B. (2006). Perception and payment of economic sanctions: A survey of offenders. Fed. Probation, 70, 26.

Ruback, R. B., Knoth, L. K., Gladfelter, A. S., \& Lantz, B. (2018). Restitution payment and recidivism: An experimental analysis. Criminology \& Public Policy, 17(4), 789-813.

Toby, J. (1957). Social disorganization and stake in conformity: Complementary factors in the predatory behavior of hoodlums. J. Crim. L. Criminology \& Police Sci., $48,12$.

Watkins, A. (2010). Decker, Scott H., and Richard T. Wright: Decisions of Street Offenders. In F. T. Cullen \& P. Wilcox (Eds.), Encyclopedia of Criminological Theory (pp. 260-263). Thousand Oaks, CA: SAGE Publications, Inc. doi: 10.4135/9781412959193.n70 


\section{Appendix}

Table 4. Frequencies for Pay and No Pay Groups

\begin{tabular}{|c|c|c|c|c|}
\hline \multirow[b]{2}{*}{ Variable } & \multicolumn{2}{|c|}{ Pay and Appeared } & \multicolumn{2}{|c|}{ No Pay and Failed to Appear } \\
\hline & $f$ & $\%$ & $f$ & $\%$ \\
\hline Any Prior Criminal History & 31 & $15.5 \%$ & 109 & $54.5 \%$ \\
\hline Repeat Evasion & 18 & $9.0 \%$ & 83 & $41.5 \%$ \\
\hline High Repeat Evasion & 1 & $0.5 \%$ & 20 & $10.0 \%$ \\
\hline Count of Evasion Cases & 18 & $9.0 \%$ & 83 & $41.5 \%$ \\
\hline Sex (Male) & 117 & $58.5 \%$ & 145 & $72.5 \%$ \\
\hline African American & 18 & $9.0 \%$ & 52 & $26.0 \%$ \\
\hline Non-White & 52 & $26.0 \%$ & 86 & $43.0 \%$ \\
\hline Live in PDX & 125 & $62.5 \%$ & 156 & $78.0 \%$ \\
\hline Repeat Address (Shelter Address) & 1 & $0.5 \%$ & 74 & $37.0 \%$ \\
\hline \multicolumn{5}{|l|}{ Months to 1st Prior Criminal Offense } \\
\hline$<1$ mo. & 0 & $6.5 \%$ & 12 & $11.9 \%$ \\
\hline 1-3 mo. & 2 & $6.5 \%$ & 18 & $24.6 \%$ \\
\hline 4-6 mo. & 2 & $9.7 \%$ & 17 & $11.0 \%$ \\
\hline 7-9 mo. & 0 & $0.0 \%$ & 9 & $5.5 \%$ \\
\hline $10-12 \mathrm{mo}$. & 0 & $0.0 \%$ & 3 & $4.6 \%$ \\
\hline 13+ mo. & 24 & $77.4 \%$ & 49 & $42.2 \%$ \\
\hline \multicolumn{5}{|l|}{ Age } \\
\hline $18-24$ & 63 & $31.5 \%$ & 45 & $22.5 \%$ \\
\hline $25-34$ & 74 & $37.0 \%$ & 63 & $31.5 \%$ \\
\hline $35-44$ & 29 & $14.5 \%$ & 40 & $20.0 \%$ \\
\hline $45-54$ & 20 & $10.0 \%$ & 31 & $15.5 \%$ \\
\hline $55+$ & 14 & $7.0 \%$ & 21 & $10.5 \%$ \\
\hline
\end{tabular}

